\title{
Analysis of cell survival genes in human gingival fibroblasts after sequential release of trichloroacetic acid and epidermal growth factor using the nano-controlled release system
}

\author{
Joon Youn Cho, Richard Leesungbok, Suk Won Lee* \\ Department of Biomaterials \& Prosthodontics, Kyung Hee University Hospital at Gangdong, School of Dentistry, Kyung Hee \\ University, Seoul, Republic of Korea
}

Purpose: This study was to determine the possible effects of trichloroacetic acid (TCA) and epidermal growth factor (EGF) through cell survival genes of the PI3K-AKT signaling pathway when applying an hydrophobically modified glycol chitosan (HGC)-based nanocontrolled release system to human gingival fibroblasts in oral soft tissue regeneration. Materials and Methods: An HGC-based nano-controlled release system was produced, followed by the loading of TCA and EGF. The group was divided into control (CON), TCA-loaded nano-controlled release system (EXP1), and the TCA- and EGF- individually loaded nano-controlled release system (EXP2). A total for 29 genes related to the PI3K-AKT signaling pathway were analyzed after $48 \mathrm{~h}$ of culture in human gingival fibroblasts. Real-time PCR, 1- way ANOVA and multiple regression analysis were performed. Results: Cell survival genes were significantly upregulated in EXP1 and EXP2. From multiple regression analysis, ITGB1 was determined to be the most influential factor for AKT1 expression. Conclusion: The application of TCA and EGF through the HGC-based nano-controlled release system can up-regulate the cell survival pathway. (J Dent Rehabil Appl Sci 2020;36(3):145-57)

Key words: human gingival fibroblast; trichloroacetic acid; epidermal growth factor; PI3K-AKT pathway; cell survival

\section{서론}

PI3K-AKT 신호전달은 세포 외 신호에 반응하여 단백 질 합성, 세포증식 및 생존을 통해 세포성장을 조절하는 신호전달이다. ${ }^{1}$ 성장인자, Chemokine, 그 외 다양한 신 호전달은 세포 표면 수용체를 활성화시키고 PI $3 \mathrm{~K}$ 의 인 산화를 유발한다. 활성화된 $\mathrm{PI} 3 \mathrm{~K}$ 는 원형질막의 지질을 인산화 하고 phosphatidylinositol $(3,4,5)$-trisphosphate (PIP3)를 생성한다. Serine/threonine-protein kinase (AKT)는 이러한 phosphoinositide docking site와 반응 하여 막 주변으로 모여 활성화된다. ${ }^{2}$ 활성화된 $\mathrm{AKT}$ 는

*Correspondence to: Suk Won Lee

Professor, Department of Biomaterials \& Prosthodontics, Kyung Hee University Hospital at Gangdong, School of Dentistry, Kyung Hee University, 892 Dongnam-ro, Gangdong-gu, Seoul, 05278, Republic of Korea

Tel: +82-2-440-7519, Fax: +82-2-440-7549, E-mail: ysprosth@hanmail.net

Received: April 21, 2020/Last Revision: May 29, 2020/Accepted: June 10, 2020
다양한 세포 내 단백질을 인산화하며 세포생존, 세포성 장, 세포증식, 세포이주 및 혈관생성에 영향을 미친다. ${ }^{3}$

Serine/threonine-protein kinase (AKT)는 세포생존, 전이, 약물 내성, 대사, 방사선 저항성을 포함하는 주요 세포 전달 체계의 주단백질이며, ${ }^{4}$ AKT1, AKT2, AKT3 등 세 가지의 $\mathrm{AKT}$ 동형단백질로 존재한다. 세 가지의 단 백질은 높은 상동 관계를 가지지만 세 가지의 다른 유전 자로부터 조직의존적으로 발현되므로 다른 기능을 가질 것이라고 추측되고 있다. 유전자제거 생쥐 연구에 따르 면 AKT1은 세포생존에 필수적이고, AKT2는 포도당 항 상성에 주된 역할을 한다고 보고되었으며, AKT3는 두

Copyright $(2020$ The Korean Academy of Stomatognathic Function and Occlusion. (c) It is identical to Creative Commons Non-Commercial License. 
뇌 발달에 영향을 미친다고 추측되고 있다. ${ }^{5} \mathrm{AKT}$ 가 억 제되면 세포생존을 위한 중요한 신호전달의 억제를 초래 할 수 있고, receptor tyrosine kinase (e.g. HER3, IGF$1 \mathrm{R}$, insulin receptor)와 같은 다른 후속 단백질이 자극되 어 이에 따라 암세포가 생존할 수 있게 된다. ${ }^{6}$

Phosphoinositide 3-kinase (PI3K)는 다양한 신호전달 에 의해 활성화되는 여러 가지 하위유형으로 나타난다. $\mathrm{PI} 3 \mathrm{~K}$ 는 receptor tyrosine kinases에 의한 인산화, ${ }^{7} \mathrm{src}$ 의 non-receptor protein tyrosine kinases(PTK), ${ }^{8}$ focal adhesion kinase ${ }^{9}$ 등에 의하여 활성화되거나 $\beta \gamma$ subunit of activated heterotrimeric $G$ proteins에 의해 활성화된다. PI3K의 길항제는 인산효소 Phosphatase and tensin homolog (PTEN) $)^{10,11}$ 와 Src homology 2 domain containing inositol polyphosphate 5-phosphatase (SHIP) ${ }^{11,12}$ 가 있으며 Phosphatidylinositol (3,4,5)-trisphosphate (PIP3)에서 인산을 제거한다.

선행연구들에서, trichloroacetic acid (TCA)의 영향이 세포수준에서 평가되었고, ${ }^{13}$ 세포 동물 모델에서 hydrophobically modified glycol chitosan (HGC)기반 나노 방출제어시스템을 사용하여 TCA와 Epidermal growth factor $(\mathrm{EGF})$ 의 영향도 평가되었다. ${ }^{14} \mathrm{TCA}$ 가 인간치은 섬유아세포에서 다양한 유전자 발현의 변화를 유도한다 는 사실이 확인되었고, TCA와 같은 강산을 구강환경에 적용 시 발생될 수 있는 위험을 해결하는 방법으로 HGC 기반 나노방출제어시스템이 제안되었다. HGC기반 나 노방출제어시스템의 안정성이 확인되었으며 TCA를 빠 르게 방출하는 동시에 EGF를 천천히 방출하는 방법이 소개되었다. 인간치은섬유아세포와 성견의 견치구개점 막의 조직세포의 유전자 발현의 변화를 또한 확인되었 다. ${ }^{13,14}$ 이전연구의 DNA microarray 분석과 successive Kyoto Encyclopedia of Genes and Genomes (KEGG) 신호전달 분석결과로부터 TCA와 EGF를 순차적으로 방출하고 적용할 때 유전자 발현이 변할 수 있는 29개의 세포생존에 관한 유전자가 선택되었다.

본 연구의 목적은 구강연조직재생에 있어 인간치은섬 유아세포에 HGC기반 TCA-와 EGF- 담지형 나노방출 제어시스템을 적용 시 TCA와 EGF의 순차적 방출이 세 포생존 유전자들의 발현에 미치는 영향을 규명하는 것이 다. 본 연구에서는 선행연구에서 언급된 PI3K-AKT 신 호전달과 연관된 29개의 유전자들에 대한 실시간 중합효 소연쇄반응 분석을 실시하였고 AKT에 대한 다른 28개 의 유전자들의 영향을 확인하였다.

\section{연구 재료 및 방법}

TCA-와 EGF- 담지형 나노방출제어시스템을 제작하기 위해 글리콜 키토산 $\left(1.0 \mathrm{~g}, 0.4 \times 10^{-5} \mathrm{~mol}\right), 5 \beta$-콜란산 $(123.0$ $\left.\mathrm{mg}, 0.34 \times 10^{-3} \mathrm{~mol}\right), \mathrm{N}$-hydroxy succinimide (NHS) (58.6 mg, $\left.0.51 \times 10^{-3} \mathrm{~mol}\right), \mathrm{N}$-(3-dimethylaminopropyl)N'-ethylcarbodiimide hydrocholoride (EDC $\cdot \mathrm{HCl})(97.6$ mg, $0.51 \times 10^{-3} \mathrm{~mol}$ ), TCA (Sigma-Aldrich Co., St. Louis, USA), 메탄올(Sigma-Aldrich Co., St. Louis, USA), EGF (Peprotech, London, UK)를 구매하였고 시약으로 사용하였다. ${ }^{14}$

$5 \beta$-콜란산을 활용한 글리콜 키토산 나노입자들 은 글리콜 키토산 $\left(1.0 \mathrm{~g}, 0.4 \times 10^{-5} \mathrm{~mol}\right)$ 과 $5 \beta$-콜란산 $\left(123.0 \mathrm{mg}, 0.34 \times 10^{-3} \mathrm{~mol}\right)$ 을 $10 \mathrm{ml}$ 의 증류수/메탄 올 용액 $(1 ; 1, \mathrm{v} / \mathrm{v})$ 에 용해하여 제작하고 뒤따라 N-(3dimethylaminopropyl)-N'-ethylcarbodiimide hydrocholoride $(\mathrm{EDC} \cdot \mathrm{HCl})\left(97.6 \mathrm{mg}, 0.51 \times 10^{-3} \mathrm{~mol}\right)$ 과 $\mathrm{N}$ hydroxysuccinimide $\left(58.6 \mathrm{mg}, 0.51 \times 10^{-3} \mathrm{~mol}\right)$ 을 24 시 간동안 교차반응시키며 첨가하였다. 투석막(molecular weight cut-off: $3,500 \mathrm{~g} / \mathrm{mol}$ )을 이용하여 24시간동안 투 석진행 후 정제하였다. 증류수/메탄올 용액(1:3; $6 \mathrm{~h}, 1: 1$; $6 \mathrm{~h}, 3: 16 \mathrm{~h}, \mathrm{v} / \mathrm{v})$ 을 투석 용매로 사용하였다. 정제과정 에서 나온 산물은 감압하 동결건조 되었고 최종 HGC 나 노입자 $\left(78.4 \%\right.$ 의 입자수득율)를 얻었다. ${ }^{14}$

TCA-담지형 나노입자들은 $10 \mathrm{ml}$ 의 증류수에 $\mathrm{HGC}$ 를 분산시켜 제조하였고, TCA $\left(1.0 \mathrm{mg}, 0.6 \times 10^{-5} \mathrm{~mol}\right)$ 를 $0.025 \mathrm{ml}$ 의 증류수에 용해하여 용액을 제작하였다. 그 후, TCA 용액을 HGC 용액에 첨가하였고, $600 \mathrm{rpm}$ 으 로 교차반응시켰다. 그 후에, TCA 입자를 정제하기 위해 24시간 투석이 투석막(MWCO: 3,500 g/mol)을 통해 진 행되었고 감압하 동결처리하여 최종 TCA-담지형 나노 입자들을 얻었다. 첨가된 TCA의 양은 이온 크로마토그 래피를 이용한 $\mathrm{Cl}$ 정량분석을 통해 측정하였다. $0.5 \%$ 의 TCA 담지형 나노입자 용액을 제조하기 위해 $4 \mathrm{ml}$ 의 증 류수를 TCA $(0.00714 \mathrm{mg}$ TCA $/ 1 \mathrm{mg}$ TCA 첨가 나노입 자)가 삽입된 $2.8 \mathrm{mg}$ 의 나노입자에 첨가하였다. ${ }^{14}$

EGF-담지형 나노입자를 제조하기 위하여, $10 \mathrm{mg}$ 의 HGC를 $10 \mathrm{ml}$ 의 증류수에 분산시킨 후 $\mathrm{EGF}(0.1 \mathrm{mg}$, $\left.0.15 \times 10^{-7} \mathrm{~mol}\right)$ 를 $0.1 \mathrm{ml}$ 의 증류수에 용해시켜 용액을 제작하였다. EGF용액을 HGC용액에 첨가 후 $300 \mathrm{rpm}$ 으로 교차반응시켰다. 그 후, 반응하지 않은 $\mathrm{EGF}$ 를 입 자들로부터 제거하기 위해 투석막(MWCO; $10,000 \mathrm{~g} /$ 
$\mathrm{mol}$ )을 통해 24시간 투석하였고 감압하 동결건조하여 최종 EGF-담지형 나노입자들을 얻었다. 담지형-EGF의 양은 ELISA (Human EGF Standard ABTS ELISA Development Kit, Peprotech, London, UK)를 통해 측정하 였다. TCA-담지형 나노입자 $(2.8 \mathrm{mg})$ 에 증류수 $2 \mathrm{ml}$ 추 가한 용액과 EGF-담지형 나노입자 $(8.98 \mu \mathrm{g}$ EGF/ $1 \mathrm{mg}$ EGF 담지형 나노입자)에 배지 $2 \mathrm{ml}$ 를 추가한 용액을 혼 합하여 $0.5 \% \mathrm{TCA}$ 담지형 나노입자와 $80 \mu \mathrm{g}$ 의 EGF 담 지형 나노입자의 복합 용액을 제조하였다. ${ }^{14}$

세포 배양을 위해 ATCC(ATCC ${ }^{\circledR}$ PCS-201-018 ${ }^{\mathrm{TM}}$, Manassas, USA)에서 인간치은섬유아세포를 구입하였다. $10 \%$ 우태아혈청 (FBS, Sigma-Aldrich Co., St. Louis,
USA)과 항생제를 포함하는 dulbecco's modified eagle's medium (DMEM, Invitrogen Corporation, Carlsbad, USA)에 세포를 부유시켰다. 부유된 인간치은섬유아세 포들은 $37^{\circ} \mathrm{C}, 95 \%$ 공기, $5 \%$ 이산화탄소 하에 humidified incubator에서 배양되었다. 2 - 3주기 동안 배양된 인 간치은섬유아세포를 본 연구에서 사용하였다. ${ }^{13}$

유전자 발현 분석을 위해 세포생존과 연관된 PI3KAKT signaling 신호전달에서 총 29개의 유전자를 선 택하였다(Table 1). ${ }^{13,14}$ 이 유전자들은 relative mRNA expression 분석을 위해 실시간 중합효소연쇄반응으 로 분석하였고 다음과 같이 분류하였다: 대조군 $(\mathrm{CON})$, TCA-담지형 나노방출제어시스템 투여군(EXP1), TCA-

Table 1. Gene information used in real-time PCR (Taqman ${ }^{\circledR}$ gene expression assay)

\begin{tabular}{|c|c|}
\hline Gene & NCBI Reference \\
\hline IGF1R, insulin like growth factor 1 receptor & NM_000875.4 \\
\hline EGFR, epidermal growth factor receptor & NM_005228.3 \\
\hline IRS1, insulin receptor substrate 1 & NM_005544.2 \\
\hline TLR2, toll like receptor 2 & NM_003264.4 \\
\hline TLR4, toll like receptor 4 & NM_003266.3 \\
\hline Rac1, Rac family small GTPase 1 & NM_006908.4 \\
\hline BCR, B cell receptor activator of RhoGEF and GTPase & NM_004327.3 \\
\hline SYK, spleen associated tyrosine kinase & NM_003177.6 \\
\hline CD19, CD19 molecule & NM_001770.5 \\
\hline PHF11, PHD finger protein 11 & NM_001040443.2 \\
\hline IL2RG, interleukin 2 receptor subunit gamma & NM_000206.2 \\
\hline JAK1, janus kinase 1 & NM_002227.3 \\
\hline JAK2, janus kinase 2 & NM_004972.3 \\
\hline JAK3, janus kinase 3 & NM_000215.3 \\
\hline ITGA5, integrin alpha 5 & NM_002205.4 \\
\hline ITGB1, integrin beta 1 & NM_002211.3 \\
\hline PTK2, protein tyrosine kinase 2 & NM_005607.4 \\
\hline PIK3CA, phosphatidylinositol-4,5-bisphosphonate 3-kinase catalytic subunit alpha & NM_006218.3 \\
\hline PIK3CB, phosphatidylinositol-4,5-bisphosphonate 3-kinase catalytic subunit beta & NM_006219.2 \\
\hline PIK3CD, phosphatidylinositol-4,5-bisphosphonate 3-kinase catalytic subunit delta & NM_005026.3 \\
\hline PIK3CG, phosphatidylinositol-4,5-bisphosphonate 3-kinase catalytic subunit gamma & NM_002649.3 \\
\hline GNB1, G protein subunit beta 1 & NM_002074.4 \\
\hline GNG2, G protein subunit gamma 2 & NM_053064.4 \\
\hline PDPK1, 3-phosphoinositol dependent protein kinase 1 & NM_002613.4 \\
\hline HP90AA1, heat shock protein 90 alpha family class a member1 & NM_010480.5 \\
\hline CDC37, cell division cycle control protein & NM_007065.3 \\
\hline mTOR, mechanistic target of rapamycin kinase & NM_004953.3 \\
\hline TCL1A, T cell leukemia/lymphoma 1 a & NM_021966.2 \\
\hline AKT, AKT serine/threonine kinase & NM_005163.2 \\
\hline
\end{tabular}


와 EGF-담지형 나노방출제어시스템 투여군(EXP2). 인 간치은섬유아세포는 24-well plate에 각 CON, EXP1, $\mathrm{EXP} 2$ 그룹으로 나누어 $37^{\circ} \mathrm{C}, 5 \%$ 이산화탄소 하에서 배 양하였고 세포 농도는 $1 \times 10^{4} / \mathrm{well}$ 로 유지하였다. 배양 48시간 후, TRIZOL lysis solution (TRIZOL ${ }^{\circledR}$ Reagent, GIBCO BRL, Carlsbad, USA)을 통해 총 RNA를 추 출하여, NanoDrop 1000 (NanoDrop Technologies, Wilmington, USA)를 사용하여 RNA의 concentration 을 진행하였다. 총 $\mathrm{RNA}$ 로부터 $1 \mu \mathrm{g}$ 추출하여 iScript cDNA Synthesis Kit (Bio-Rad Laboratories, Berkeley, $\mathrm{USA}$ )를 이용하여 $\mathrm{cDNA}$ 로 역전사시켰다. 유전자 발현 은 TaqMan ${ }^{\circledR}$ Gene Expression Assay Kit (Applied Biosystems, Waltham, USA)을 사용하여 확인하였다. 본 연 구의 실시간 중합효소연쇄반응으로 사용된 유전자들은 Table 1과 같이 정리하였다. Chromo4 reverse transcription-polymerase chain reaction (Bio-Rad Laboratories, Hemel Hepstead, UK)은 iQ Supermix (Bio-Rad)를 사 용하여 진행하였다. 유전자 발현은 MJ OPticon Monitor Analysis Software (Bio-Rad)를 이용하여 정량화하였 다. ${ }^{13}$ 측정된 값은 $\mathrm{GAPDH}$ 의 발현 레벨에 의해 수정되었 고 $\mathrm{EXP} 1$ 과 EXP2의 발현 레벨은 다수의 $\mathrm{CON}$ 에서 표 현되었다.

유전자들의 발현량에 대한 실시간 중합효소연쇄반응 을 각 유전자마다 독립적으로 5 회 반복 진행하였고, 평 균값과 표준편차를 계산하였다. 평균값을 비교하기 위하 여 일요인분산분석을 시행하였고, post-hoc 비교를 위해 Tukey's multiple comparison test $\mathrm{B}$ 를 진행하였다. AKT 발현에 통계학적으로 유의미한 영향을 미친 유전자를 결 정하기 위해 단계적 다중회귀분석을 시행하였다. 모든 통계 분석을 위해 SPSS 18.0 software (SPSS 18.0, SPSS Inc., Chicago, USA)를 사용하였다.

\section{결과}

나노방출제어시스템에서 HGC 나노입자들은 캡슐 화되어 있으며 화학물질을 방출하고 중성 $\mathrm{pH}$ 용액에서 잘 용해된다. ${ }^{14}$ Chitosan의 hydrophilic cationic amine group (-NH2)는 hydrophobic cholanic acid와 결합한다. Hydrophobic cholanic acid는 물에서 핵을 형성하는 반 면 hydrophilic cationic chitosan은 겉껍질을 형성하였다. 음이온의 TCA와 EGF는 이온결합을 통해 chitosan 껍 질에 담지되었으며 in vitro와 in vivo 상황에서 순차적으
로 방출될 것으로 생각되었다(Fig. 1). ${ }^{14}$

실험 48시간 이후 실시간 중합효소연쇄반응 분석을 통 하여 상향 조절된 유전자를 확인하였다. 성장인자와 연 관된 신호전달의 유전자 실시간 중합효소연쇄반응 분석 결과는 다음과 같다. Insulin like growth factor 1 receptor (IGF1R), epidermal growth factor receptor (EFGR), insulin receptor substrate 1 (IRS1)은 대조군에 비하 여 EXP1과 EXP2에서 상향조절되었으며 $(P<0.001)$, $\mathrm{EXP} 2, \mathrm{EXP} 1, \mathrm{CON}$ 순으로 유의미한 상향조절이 관찰 되었다 $(P<0.001$, Fig. 2).

Toll-like receptor signaling 신호전달의 유전자 실시 간 중합효소연쇄반응 분석 결과는 다음과 같다. Toll like receptor 2 (TLR2)에서는 대조군에 비하여 EXP2에서 유의미한 상향조절이 관찰되었다 $(P<0.01)$. Toll-like receptor 4 (TLR4)는 대조군에 비하여 EXP2와 EXP1에 서 상향조절되었으며 $(P<0.001), \mathrm{EXP} 2$ 와 EXP1사이에 는 유의미한 차이가 없었다. Rac family small GTPase 1 (Rac1)은 대조군에 비하여 EXP1과 EXP2에서 상향조절 되었으며 $(P<0.001), \mathrm{EXP} 2, \mathrm{EXP} 1, \mathrm{CON}$ 순으로 유의 미한 상향조절이 관찰되었다 $(P<0.001, \mathrm{Fig} .2)$.

$\mathrm{B}$ cell receptor signaling 신호전달의 유전자 실시간 중 합효소연쇄반응 분석 결과는 다음과 같다. B cell receptor activator for RhoGEF and GTPase (BCR)과 CD19 molecule (CD19)는 CON, EXP1, EXP2 사이에 어떠한 상관관계도 관찰되지 않았다. Spleen associated tyrosine kinase (SYK)와 PHD finger protein 11 (PHF11)은 대조 군에 비하여 EXP2에서 유의미하게 상향조절되었다(각 각 $P<0.001, P<0.01$ )(Fig. 2).

JAK/STAT signaling 신호전달의 유전자 실시간 중합 효소연쇄반응 분석 결과는 다음과 같다. Interleukin 2 receptor subunit gamma (IL2RG)는 CON, EXP, EXP2 사이에 어떠한 상관관계도 관찰되지 않았다. Janus kinase 1 (JAK1)과 Janus kinase 3 (JAK3)는 대조군에 비 하여 EXP1과 EXP2에서 상향조절되었으며 $(P<0.001)$, $\mathrm{EXP} 2, \mathrm{EXP} 1, \mathrm{CON}$ 순으로 유의미한 상향조절이 관 찰되었다 $(P<0.001)$. Janus kinase 2 (JAK2)는 대조군 에 비하여 EXP2과 EXP1에서 상향조절되었고 EXP2와 EXP1 사이에 유의한 차이는 없었다 $(P<0.01$, Fig. 2).

국소 접착과 연관된 신호전달의 유전자 실시간 중합효 소연쇄반응 분석 결과는 다음과 같다. Integrin alpha 5 (ITGA5), integrin beta 1 (ITGB1)과, protein tyrosine kinase 2 (PTK2)는 대조군에 비하여 EXP1과 EXP2에 


\section{Cholanic acid-conjugated chitosan}
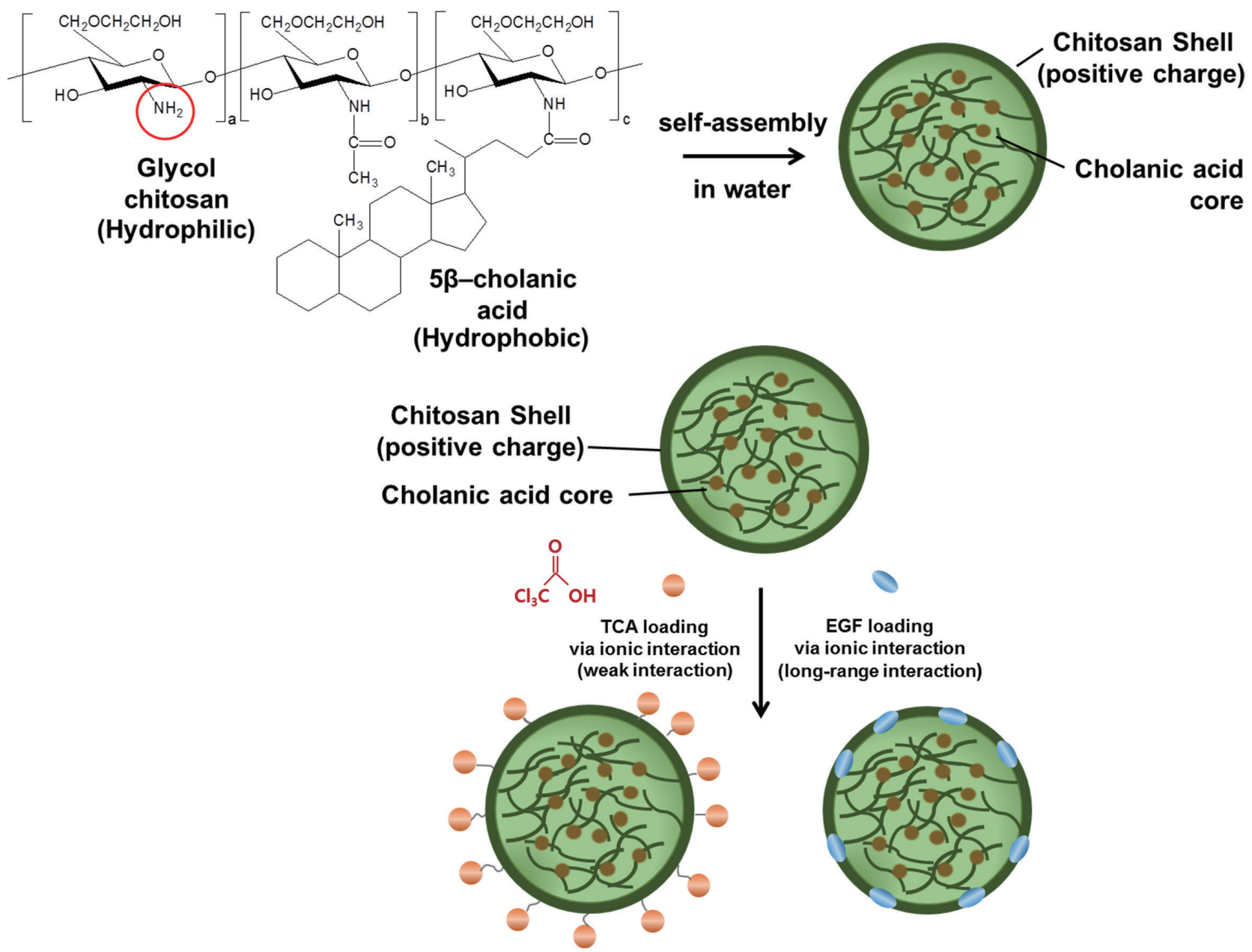

Fig. 1. Principle of HGC-based TCA- and EGF- loaded nano-controlled release system. The hydrophilic cationic amine group (-NH2) of chitosan was combined with hydrophobic cholanic acid. Hydrophobic cholanic acid formed nuclei in water, while hydrophilic cationic chitosan formed the outer shell. The anionic TCA and EGF were loaded on the chitosan shell through ion bonding.

서 상향조절되었으며 $(P<0.001), \mathrm{EXP} 2, \mathrm{EXP} 1, \mathrm{CON}$ 순으로 유의미한 상향조절이 관찰되었다 $(P<0.001$, Fig. 2).

Chemokine signaling 신호전달의 유전자 실시간 중합 효소연쇄반응 분석 결과는 다음과 같다. $G$ protein subunit beta 1 (GNB1)은 대조군에 비하여 EXP1과 EXP2 에서 상향조절되었으며 $(P<0.001), \mathrm{EXP} 2, \mathrm{EXP} 1, \mathrm{CON}$ 순으로 유의미한 상향조절이 관찰되었다 $(P<0.001) . \mathrm{G}$ protein subunit gamma 2 (GNG2)은 대조군에 비하여 $\mathrm{EXP} 2$ 와 EXP1에서 상향조절되었고 EXP2와 EXP1사 이에 유의한 차이는 없었다 $(P<0.001$, Fig. 3$)$.
PI3K-AKT 신호전달에서 AKT 생성에 직접적으로 관 여하는 유전자 실시간 중합효소연쇄반응 분석 결과는 다 음과 같다. 3-phosphoinositol dependent protein kinase 1 (PDPK1)은 대조군에 비하여 EXP2와 EXP1에서 하 향조절되었다 $(P<0.001)$. Heat shock protein 90 alpha family class a member 1 (HP90AA1)과 cell division cycle control protein (CDC37)은 대조군에 비하여 EXP1 과 EXP2에서 상향조절되었으며 $(P<0.001), \mathrm{EXP} 2$, $\mathrm{EXP} 1, \mathrm{CON}$ 순으로 유의미한 상향조절이 관찰되었다 $(P<0.001)$. Mechanistic target of rapamycin kinase (mTOR)은 대조군에 비하여 EXP2에서 하향조절되었다 

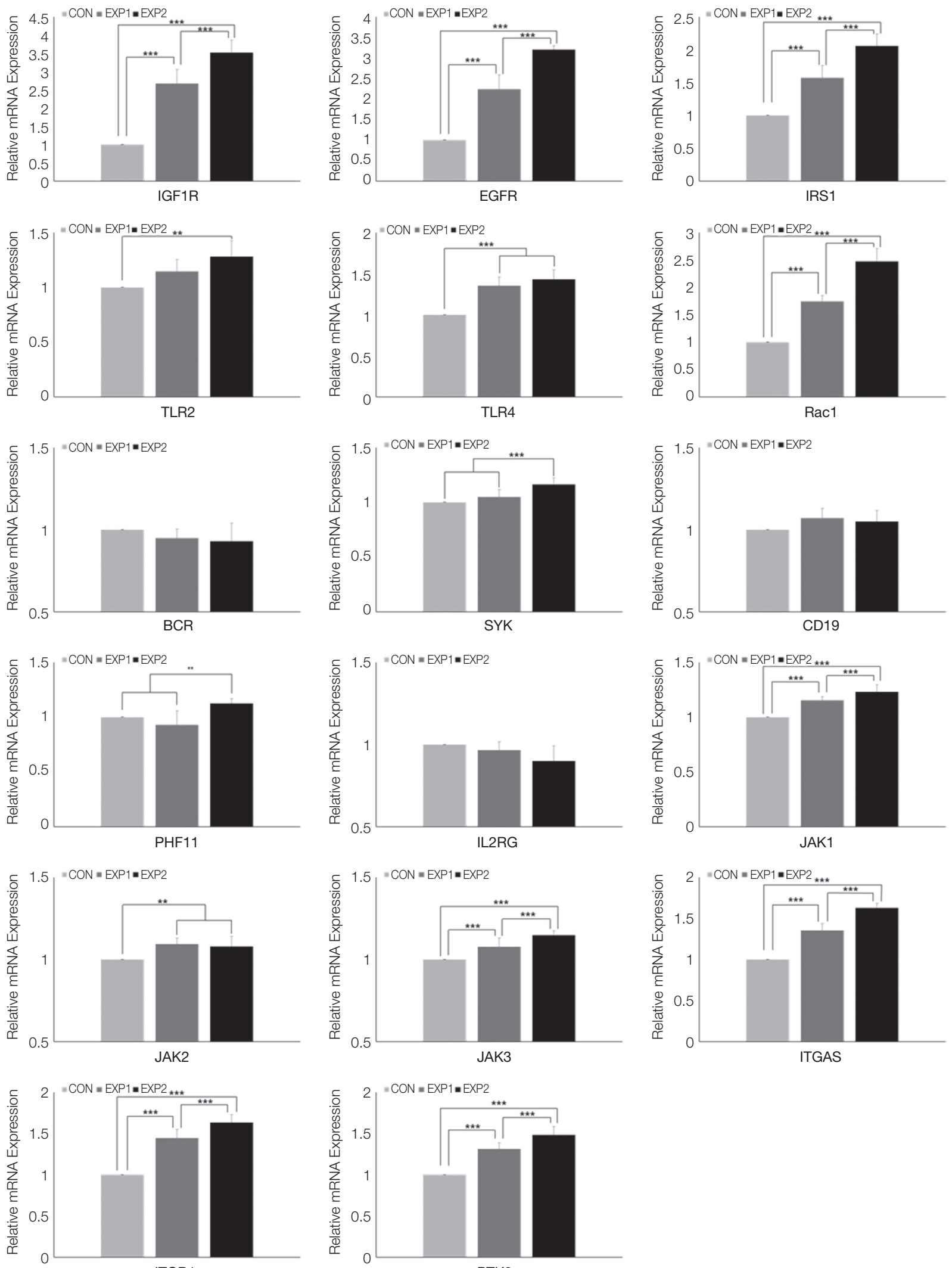

PTK2

Fig. 2. Real-time PCR analysis results of Growth factor (IGF1R, EFGR, IRS1), Toll-like receptor signaling pathway (TLR2, TLR4, Rac1), B cell receptor (BCR) signaling pathway (BCR, SYK, CD19, PHF11), JAK/STAT signaling pathway (IL2RG, JAK1, JAK2, JAK3), Focal adhesion associated genes (ITGA5, ITGB1, PTK2). One-way ANOVA (***: $P<0.001, * *: P<0.01, *: P<$ $0.05)$. 

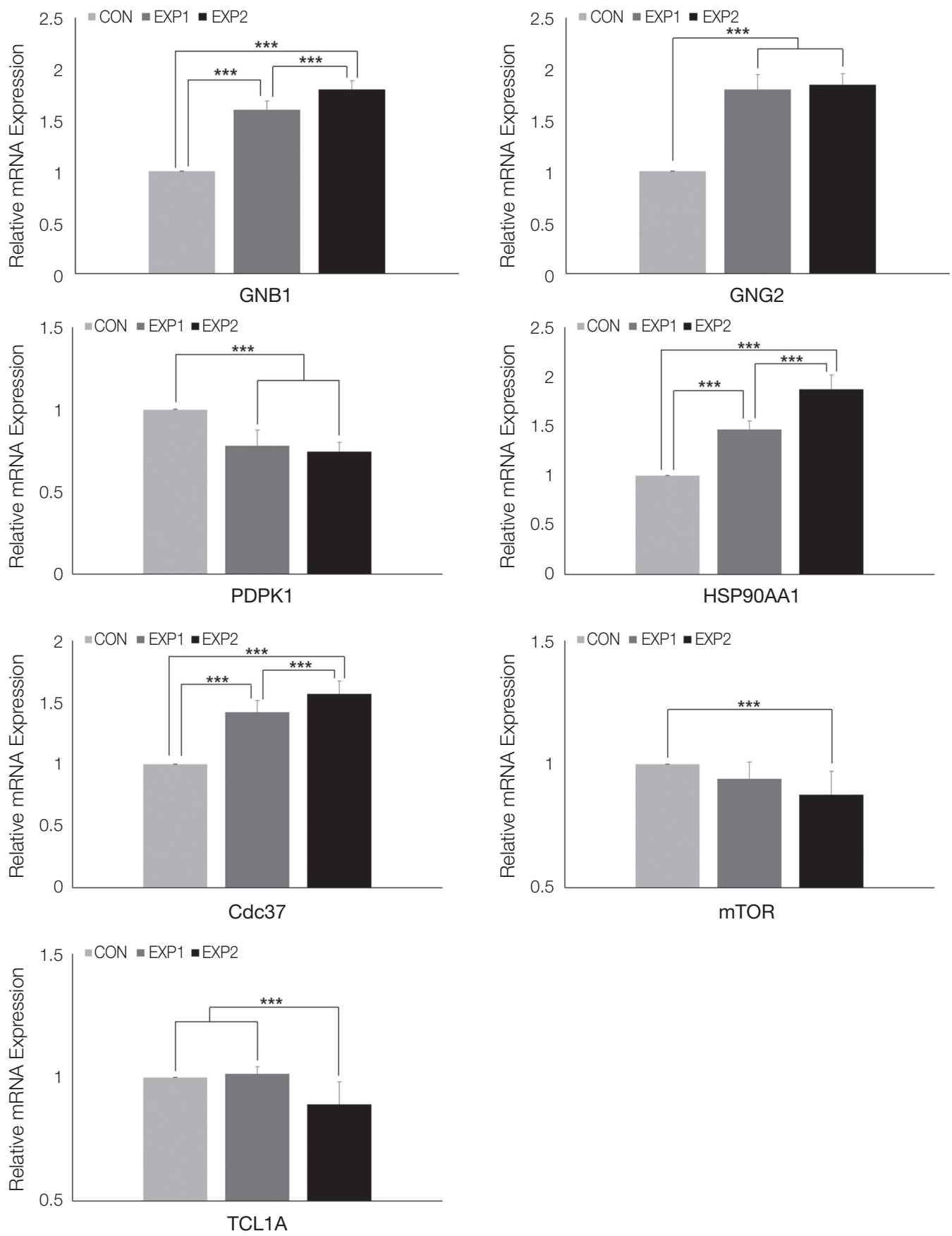

Fig. 3. Real-time PCR analysis results of Chemokine signaling pathway associated genes (GNB1, GNG2) and other genes directly involved in AKT production (PDPK1, HSP90AA1, Cdc37, mTOR, TCL1A). One-way ANOVA (***: $P<0.001)$.

$(P<0.001)$. T cell leukemia/lymphoma 1 a $($ TCL1A)는 대조군에 비하여 EXP2에서 하향조절되었다 $(P<0.001$, Fig. 3).

$\mathrm{PI} 3 \mathrm{~K}$ 의 유전자 실시간 중합효소연쇄반응 분석 결과는 다음과 같다. Phosphatidylinositol-4,5-bisphosphonate 3-kinase catalytic subunit alpha (PI3KCA), Phospha- tidylinositol-4,5-bisphosphonate 3-kinase catalytic subunit delta (PI3KCD)과, Phosphatidylinositol-4,5bisphosphonate 3-kinase catalytic subunit gamma (PI3KCG)은 대조군에 비하여 EXP1과 EXP2에서 상 향조절되었으며 $(P<0.001), \mathrm{EXP} 2, \mathrm{EXP} 1, \mathrm{CON}$ 순으 로 유의미한 발현 증가가 관찰되었다 $(P<0.001)$. Phos- 
phatidylinositol-4,5-bisphosphonate 3-kinase catalytic subunit beta (PI3KCB)는 대조군에 비하여 EXP1과 $\mathrm{EXP} 2$ 에서 상향조절이 관찰되었고 $\mathrm{EXP} 1$ 과 EXP2 사 이에 유의한 차이는 없었다 $(P<0.001$, Fig. 4). AKT1 유 전자 실시간 중합효소연쇄반응 분석 결과, 대조군에 비 하여 $\mathrm{EXP} 1$ 과 $\mathrm{EXP} 2$ 에서 상향조절되었으며 $(P<0.001)$, $\mathrm{EXP} 2, \mathrm{EXP} 1, \mathrm{CON}$ 순으로 유의미한 상향조절이 관찰 되었다 $(P<0.001$, Fig. 5).
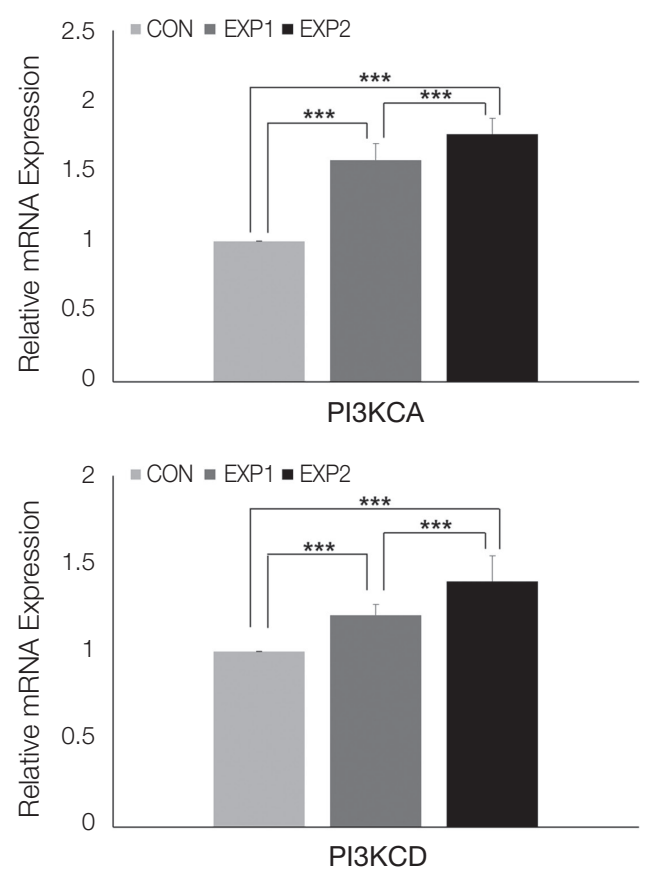

$\mathrm{AKT}$ 에 가장 유의미하게 영향을 미친 유전자를 확 인하기 위해 다중회귀분석을 진행하였고 종속변수로 $\mathrm{AKT} 1$ 을 설정하였으며 본 연구에 사용된 유전자를 독 립변수로 설정하였다. ITGB1, CD19, JAK3, PHF11, $\mathrm{PDPK} 1, \mathrm{GNB} 1$ 이 AKT1 표현에 영향을 주는 요소 로 선택되었다 $(P<0.001)$. 가장 영향력 있는 유전자는 ITGB1으로 확인되었다 $(P<0.001$, Table 2$)$.
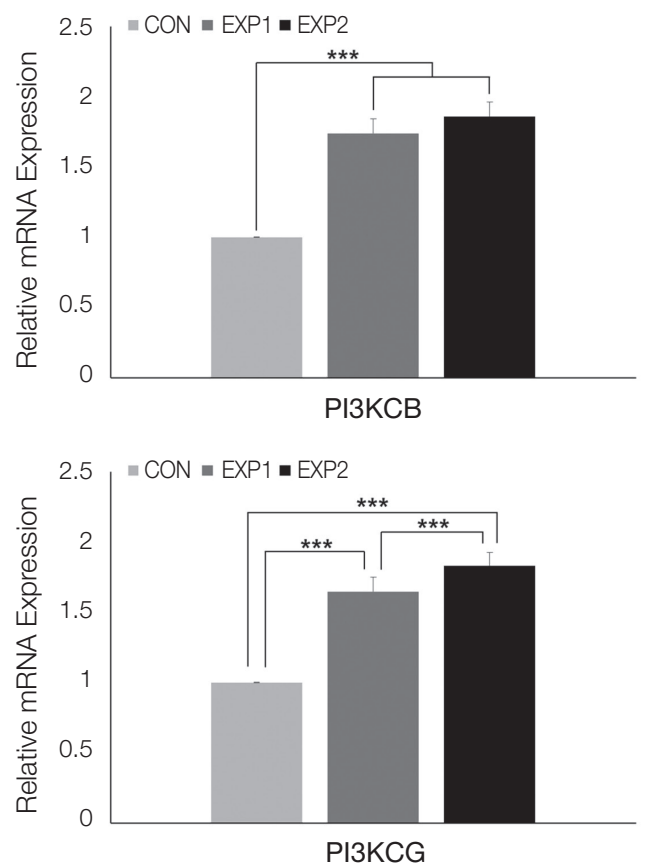

Fig. 4. Real-time PCR analysis results of PI3K genes (PI3KCA, PI3KCB, PI3KCD, PI3KCG). One-way ANOVA (***: $P<0.001)$.

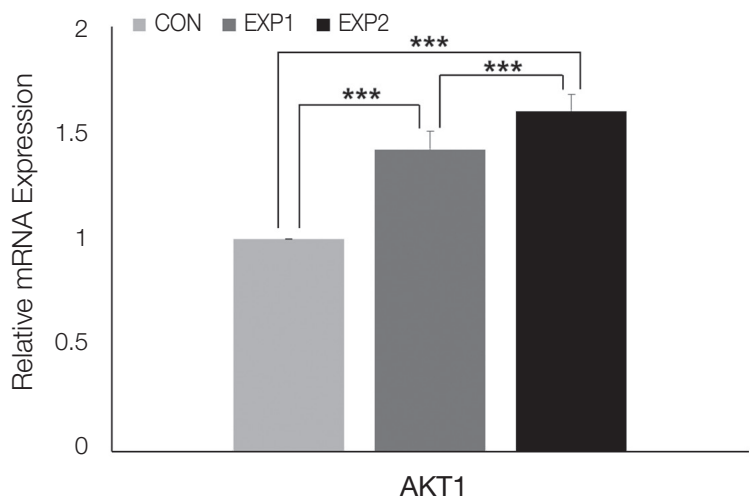

Fig. 5. Real-time PCR analysis results of AKT1. One-way ANOVA (***: $P<0.001)$. 
Table 2. The influential factors on the expression of AKT1 after administration of the nano controlled release system to induce sequential release of TCA and EGF, as determined by multiple regression analysis

\begin{tabular}{|c|c|c|c|c|c|}
\hline $\begin{array}{l}\text { Dependent } \\
\text { variable }\end{array}$ & Model & Regression Results & $\mathrm{R}$ & $\mathrm{R}^{2}$ & Sig. $^{1)}$ \\
\hline \multirow{6}{*}{ AKT1 } & 1 & $\mathrm{AKT} 1=0.061+0.941 \cdot[\mathrm{ITGB} 1]$ & 0.999 & 0.998 & $<0.001$ \\
\hline & 2 & $\mathrm{AKT} 1=0.264+0.969 \cdot[\mathrm{ITGB} 1]-0.213 \cdot[\mathrm{CD} 19]$ & 1.000 & 0.999 & $<0.001$ \\
\hline & 3 & $\begin{aligned} \mathrm{AKT} 1= & 0.401+1.019 \cdot[\mathrm{ITGB} 1]-0.197 \cdot[\mathrm{CD} 19] \\
& -0.223 \cdot[\mathrm{JAK} 3]\end{aligned}$ & 1.000 & 1.000 & $<0.001$ \\
\hline & 4 & $\begin{aligned} \mathrm{AKT} 1= & 0.666+1.108 \cdot[\mathrm{ITGB} 1]-0.184 \cdot[\mathrm{CD} 19] \\
& -0.699 \cdot[\mathrm{JAK} 3]+0.109 \cdot[\mathrm{PHF} 11]\end{aligned}$ & 1.000 & 1.000 & $<0.001$ \\
\hline & 5 & $\begin{aligned} \text { AKT1 }= & 1.261+1.157 \cdot[\text { ITGB1] }-0.244 \cdot[\mathrm{CD} 19] \\
& -1.240 \cdot[\mathrm{JAK} 3]+0.215 \cdot[\mathrm{PHF} 11]-0.150 \cdot[\mathrm{PDPK} 1]\end{aligned}$ & 1.000 & 1.000 & $<0.001$ \\
\hline & 6 & $\begin{aligned} \text { AKT1 }= & 1.122+0998 \cdot[\text { [TGB1 }]-0.169 \cdot[\mathrm{CD} 19] \\
& -1.216 \cdot[\mathrm{JAK} 3]+0.251 \cdot[\mathrm{PHF} 11]-0.110 \cdot[\mathrm{PDPK} 1] \\
& +0.124 \cdot[\mathrm{GNB} 1]\end{aligned}$ & 1.000 & 1.000 & $<0.001$ \\
\hline
\end{tabular}

1) Significances of each regression model were tested by analysis of variance $(\mathrm{n}=15)$.

$\mathrm{R}$ : coefficient of multiple correlations.

$\mathrm{R}^{2}$ : coefficient of determination.

\section{고찰}

세포생존과 증식에 중요한 조절요소로 기능을 하는 것 은 AKT이다. ${ }^{15}$ AKT는 보존된 domain 구조를 가지고 있고, 특정 $\mathrm{pH}$ domain, 중앙 kinase domain, signaling 분 자들과 상호관계를 조절하는 carboxyl-terminal 조절 domain을 지니고 있다. ${ }^{15} \mathrm{AKT}$ 와 함께 PI3K도 성장인자와 다른 세포 외 자극들에 의해 반응하는 signaling 신호전 달 안에서 중요한 역할을 담당하고, 영양대사, 세포성장, 세포사멸, 세포생존을 포함한 다양한 세포 기능을 조절 하는데 영향을 미친다. ${ }^{15}$ 선행예비연구들에서 HGC기반 TCA-와 EGF-담지형 나노방출제어시스템을 투여 시 단 백질합성, 세포증식, 세포생존 등에 관련된 신호전달에 서 상향조절되는 유전자들이 보고되었으며, 본 연구에서 는 특별히, TCA와 EGF 투여 시 인간치은섬유아세포의 PI3K-AKT 신호전달에서 유전자 발현의 변화를 알아보 았다. IGFR과 EGFR은 receptor tyrosine kinase (RTK) 로 통칭될 수 있으며, 이러한 RTK들은 성장인자와 같 은 polypeptide ligand와 결합하여 세포 반응을 조절하는 signaling cascade를 촉진한다. ${ }^{16}$ IRS는 인산화된 IGF1R 에 의해 활성화되고 IRS는 PI3K의 활성에 도움을 주 는 scaffold 역할을 한다. ${ }^{17}$ 본 연구에서 IGF1R, EGFR, IRS1의 real time-PCR 분석 결과 EXP1과 EXP2에서 모 두 유의하게 발현이 증가되었으며, EXP2에서 증가된 발 현량이 EXP1보다 많았고, 이러한 유전자들의 발현량 증
가는 PI3K와 AKT의 활성 증가를 이끌 수 있음을 의미 한다. EXP1에서 증가된 발현량이 EXP2보다 적은 것은 $\mathrm{EXP} 1$ 에서 TCA의 독성이 영향을 미쳤을 것으로 생각 된다. TLR은 선천 면역 센서 중 하나로 pathogen-associated molecular patterns (PAMPs)를 인식한다. TLR은 염증반응을 일으키며 PI3K를 활성화시킨다. ${ }^{18} \mathrm{TLR} 2$ 는 EXP2에서만 유의미하게 발현량이 증가되었고 TLR4는 $\mathrm{EXP} 2$ 와 EXP1에서 유의미한 발현량 증가가 모두 관찰 되었다. Rac1은 EXP1과 EXP2에서 모두 유의미하게 발 현이 증가되었으며 EXP2에서 증가된 발현량이 EXP1보 다 많았다. EXP1에서 TLR2는 유의미한 발현량 증가를 보이지 않았으나 TLR4에서는 유의미한 발현량 증가를 보였고 EXP2에서 TLR2와 TLR4에서 모두 유의미한 발 현량 증가를 보였으므로 TLR2와 TLR4에 의해 활성화 되는 Rac1은 EXP2에서 더 많은 발현량 증가를 했다고 유추할 수 있다. SYK는 BCR이 항원을 인지한 이후 B 림 프구의 활성에 중요한 유전자이다. BCR에 의한 SYK의 군집은 이후 PI3K를 포함하는 signaling의 활성에 필수 요소이다. ${ }^{19} \mathrm{CD} 19$ 는 $\mathrm{BCR}$ 과 떨어져 있지만 활성화된 B cell 표면과 연관성이 있어 유사한 측면을 보이고 SYK의 tyrosine 인산화와 연관이 있다. ${ }^{20}$ 활성화된 SYK와 같은 protein tyrosine kinase (PTK)는 PHF11과 같은 세포질 수용체 단백질을 인산화 ${ }^{21}$ 하고 $\mathrm{PHF} 11$ 은 $\mathrm{BCR}$ 자극 이 후 인산화되어 $\mathrm{PI} 3 \mathrm{~K}$ 활성에 영향을 미친다. ${ }^{22}$ 본 연구에 서 $\mathrm{EXP} 1$ 과 $\mathrm{EXP} 2$ 에서 $\mathrm{BCR}$ 과 $\mathrm{CD} 19$ 는 유의미한 변화 
를 보이지 않았고 SYK와 PHF11은 EXP2에서만 유의미 한 발현량 증가를 보였다. 세포표면에 존재하는 BCR은 항원에 반응하여 활성화되는 단백질이지만 본 연구에서 는 항원에 관한 실험이 없기 때문에 유의미한 변화를 보 이지 않은 것으로 추측되며, $\mathrm{BCR}$ 의 활성에 따라 $\mathrm{CD} 19$ 의 활성도 변화하기 때문에 CD19도 유의미한 변화를 보 이지 않았다. 세포질의 SYK와 PHF11은 EXP2에서 발 현량이 증가되었는데 EXP1에서는 TCA의 독성이 영향 을 미친 것으로 보인다. IL2RG는 골수의 미성숙 혈액 생 성 세포의 표면에 위치한 단백질로 사이토카인 수용체 이다. IL2RG의 활성은 IL2 signaling에 필요하며 tyrosine phosphorylation을 야기하여 Janus family tyrosine kinases (e.g. JAK1, JAK3)를 활성화시킨다. ${ }^{23} \mathrm{JAK}$ 가 인 산화되면 결과적으로 $\mathrm{PI} 3 \mathrm{~K}$ 신호전달을 활성화시킨다. ${ }^{24}$ 본 연구에서 EXP1과 EXP2에서 IL2RG 유의미한 변화 를 보이지 않았고 JAK1과 JAK3는 EXP1과 EXP2에서 모두 유의미하게 발현량이 증가되었으며 EXP2에서 증 가된 발현량이 EXP1보다 많았다. Extracellular matrix (ECM)이 integrin receptor (e.g. ITGA5, ITGB1)에 의 해 군집되면 Focal adhesion kinase (FAK)(e.g. PTK2)는 integrin에 반응하여 인산화되며 PI3K 신호전달의 활성 에 영향을 준다. ${ }^{25}$ 본 연구에서 ITGA5, ITGB1, PTK2의 real time-PCR 분석 결과 EXP1과 EXP2에서 모두 유의 미하게 발현량이 증가되었으며 EXP2에서 증가된 발현 량이 EXP1보다 많았다.

세포 외의 chemokine, hormone 등이 세포 표면의 Gprotein-coupled receptor (GPCR)과 결합하면 세포내 의 $\mathrm{G}$ protein (e.g. GNB1, GNG2)의 상호관계를 이끌 고 신호를 전달하게 하여 PI3K와 같은 downstream signal transduction 신호전달을 유발한다. ${ }^{26}$ 본 연구에 서 G-protein 중 GNB1과 GNG2의 실시간 중합효소연 쇄반응 분석을 통해 EXP1과 EXP2에서 발현량이 증가 된 것을 관찰하였다. $\mathrm{PI} 3 \mathrm{~K}$ 의 형성은 PDPK1과 $\mathrm{AKT}$ 의 membrane-based colocalization를 촉진시킨다. PDPK1 은 자신의 T-loop를 인산화시키는 능력으로 인해 세포 안에서 구성적으로 활성화된다. PDPK1가 membrane으 로 이동하면서 mTOR2와 함께 AKT1의 활성화를 돕는 다. ${ }^{27}$ TCL1A 또한 AKT의 Pleckstrin homology domain 에 결합하여 $\mathrm{AKT}$ 활성에 영향을 준다. ${ }^{28}$ 그러나 본 연구 에서는 PDPK1, mTOR, TCL1A는 EXP1과 EXP2에서 발현량이 감소되었다. TCA와 EGF 투여 시 발현량이 감 소하는 것에 대해서는 추가적인 연구 및 고찰이 필요하
다. HSP90AA1과 CDC37은 복합체로서 세포 내 AKT 와 관련이 있다. HSP90AA1은 복합체 내에서 AKT의 안 정성을 위해 필요하다. ${ }^{29} \mathrm{HSP} 90 \mathrm{AA} 1$ 과 CDC37은 EXP1 과 EXP2에서 모두 유의미하게 발현이 증가되었으며 $\mathrm{EXP} 2$ 에서 증가된 발현량이 EXP1보다 많았다. PI3K$\mathrm{AKT}$ signaling 신호전달에서 여러 신호전달의 단백질 로부터 활성화된 PI3K는 $\mathrm{AKT}$ 를 활성화시키고 $\mathrm{AKT}$ 는 세포생존, 성장, 증식, 세포이주 및 혈관생성에 기여한 다. ${ }^{2,3} \mathrm{EXP} 1$ 과 EXP2에서 PI3KCA, PI3KCB, PI3KCD, PI3KCG, AKT1 모두 발현이 증가되었다.

세포생존과 관련된 PI3K-AKT signaling 신호전달 의 29개의 유전자에 대해 비교 분석한 결과 HGC기반 TCA-와 EGF-담지형 나노방출제어시스템이 PI3K$\mathrm{AKT}$ 신호전달에서 여러 유전자의 발현량을 증가시키 고 어떠한 유전자가 세포생존에 영향을 줄 수 있는지 확 인할 수 있었다. 다만, 이러한 반응은 항상 일정하지 않으 며 그 이유는 TCA의 세포독성인 것으로 추측된다. 상향 조절된 PI3KCA, PI3KCB, PI3KCD, PI3KCG, AKT1 은 세포생존에 중요한 역할을 수행한다. AKT는 세포생 존, 전이, 약물 내성, 대사, 방사선 저항성을 포함하는 주 요 세포 전달 체계의 주단백질이며 활성화된 AKT는 다 양한 세포 내 단백질을 인산화하며 세포생존, 성장, 증 식, 세포이주 및 혈관생성에 영향을 미친다. ${ }^{3,4}$ 이에 따라, $\mathrm{AKT}$ 의 발현량 결과값을 종속변수로 설정하여 다중회귀 분석을 실시하였다. 다중회귀분석 결과로써 가장 유의미 한 영향을 주는 요소는 ITGB1이었다. ECM과 결합되어 PI3K 생성을 촉진하는 ITGB1이 세포생존 및 증식 등의 주요 세포 전달체계의 주단백질인 AKT 발현에 가장 영 향력 있는 유전자라는 것이 본 연구에서 규명되었다.

\section{결론}

본 연구의 결과에 따라, $\mathrm{HGC}$ 기반 나노방출제어시스 템을 이용한 TCA와 EGF의 적용은 인간치은섬유아세 포에서 각종 유전자들 상향조절에 의한 AKT 발현 촉진 으로 세포생존에 연관된 신호전달을 활성화시킬 수 있음 을 알 수 있다.

\section{Acknowledgements}

This research was supported by a grant of the Korea Health Technology R\&D Project through the Korea 
Health Industry Development Institute (KHIDI), funded by the Ministry of Health \& Welfare, Republic of Korea (grant number: HI16C1838).

\section{ORCID}

Joon Youn Cho https://orcid.org/0000-0002-4306-3816

Richard Leesungbok https://orcid.org/0000-00028381-723X

Suk Won Lee https://orcid.org/0000-0003-2726-3567

\section{References}

1. Yu JS, Cui W. Proliferation, survival and metabolism: the role of $\mathrm{PI} 3 \mathrm{~K} / \mathrm{AKT} / \mathrm{mTOR}$ signalling in pluripotency and cell fate determination. Development 2016;143:3050-60.

2. Osaki M, Oshimura M, Ito H. The PI3K-Akt pathway: Its functions and alterations in human cancer. Apoptosis 2004;9:667-76.

3. Manning BD, Cantley LC. AKT/PKB Signaling: Navigating Downstream. Cell 2007;129:1261-74.

4. Cheung M, Testa JR. Diverse mechanisms of AKT pathway activation in human malignancy. Curr Cancer Drug Targets 2013;13:234-44.

5. Romano G. The role of the dysfunctional aktrelated pathway in cancer: Establishment and maintenance of a malignant cell phenotype, resistance to therapy, and future strategies for drug development. Scientifica (Cairo) 2013;2013:317186.

6. Virtakoivu R, Pellinen T, Rantala JK, Perälä M, Ivaska J. Distinct roles of AKT isoforms in regulating $\beta 1$-integrin activity, migration, and invasion in prostate cancer. Mol Biol Cell 2012;23:3357-69.

7. Brock C, Schaefer M, Reusch HP, Czupalla C, Michalke M, Spicher K, Schultz G, Nürnberg B. Roles of $G \beta \gamma$ in membrane recruitment and activation of p110 $/ \mathrm{p} 101$ phosphoinositide 3-kinase $\gamma$. J Cell Biol 2003;160:89-99.

8. Stephens L, Eguinoa A, Corey S, Jackson T, Hawkins PT. Receptor stimulated accumulation of phosphatidylinositol $(3,4,5)$-trisphosphate by Gprotein mediated pathways in human myeloid derived cells. EMBO J 1993;12:2265-73.
9. Reiske HR, Zhao J, Han DC, Cooper LA, Guan JL. Analysis of FAK-associated signaling pathways in the regulation of cell cycle progression. FEBS Lett 2000;486:275-80.

10. Hlobilková A, Knillová J, Bártek J, Lukás J, Kolár $Z$. The mechanism of action of the tumour suppressor gene PTEN. Biomed Pap Med Fac Univ Palacky Olomouc Czech Repub 2003;147:19-25.

11. Sly LM, Rauh MJ, Kalesnikoff J, Büchse T, Krystal G. SHIP, SHIP2, and PTEN activities are regulated in vivo by modulation of their protein levels: SHIP is up-regulated in macrophages and mast cells by lipopolysaccharide. Exp Hematol 2003;31:1170-81.

12. Kalesnikoff J, Sly LM, Hughes MR, Büchse T, Rauh MJ, Cao LP, Lam V, Mui A, Huber M, Krystal G. The role of SHIP in cytokine-induced signaling. Rev Physiol Biochem Pharmacol 2003;149:87-103.

13. Lee KH, Ben Amara H, Lee SC, Leesungbok R, Chung MA, Koo KT, Lee SW. Chemical regeneration of wound defects: relevance to the canine palatal mucosa and cell cycle up-regulation in human gingival fibroblasts. Tissue Eng Regen Med 2019;16:675-84.

14. Park KM, Lee HJ, Koo KT, Ben Amara HB, Leesungbok R, Noh K, Lee SC, Lee SW. Oral soft tissue regeneration using the nano controlled system inducing sequential release of trichloroacetic acid and epidermal growth factor. Tissue Eng Regen Med 2020;17:91-103.

15. Song G, Ouyang G, Bao S. The activation of Akt/ PKB signaling pathway and cell survival. J Cell Mol Med 2005;9:59-71.

16. Lateef Z, Wise LM. Exploitation of receptor tyrosine kinases by viral-encoded growth factors. Growth factors 2018;36:118-40.

17. White MF, Kahn CR. The insulin signaling system. J Biol Chem 1994;269:1-4.

18. Kawai T, Akira $\mathrm{S}$. The role of pattern-recognition receptors in innate immunity: update on Toll-like receptors. Nat Immunol 2010;11:373-84.

19. Yokozeki T, Adler K, Lankar D, Bonnerot C. B cell receptor-mediated Syk-independent activation of phosphatidylinositol 3-kinase, Ras, and mitogenactivated protein kinase pathways. J Immunol 2003; 171:1328-35. 
20. Lankester AC, Rood PM, van Schijndel GM, Hooibrink B, Verhoeven AJ, van Lier RA. Alteration of B-cell antigen receptor signaling by CD19 coligation. A study with bispecific antibodies. J Biol Chem 1996;271:22326-30.

21. Kurosaki T. Regulation of B-cell signal transduction by adaptor proteins. Nat Rev Immunol 2002;2:35463.

22. Yamazaki T, Takeda K, Gotoh K, Takeshima H, Akira S, Kurosaki T. Essential immunoregulatory role for BCAP in B cell development and function. J Exp Med 2002;195:535-45.

23. Russell SM, Johnston JA, Noguchi M, Kawamura M, Bacon CM, Friedmann M, Berg M, McVicar DW, Witthuhn BA, Silvennoinen O, et al. Interaction of IL-2R beta and gamma c chains with Jak1 and Jak3: implications for XSCID and XCID. Science. 1994;266:1042-5.

24. Foster FM, Traer CJ, Abraham SM, Fry MJ. The phosphoinositide (PI) 3-kinase family. J Cell Sci 2003;116(Pt 15):3037-40.

25. Burridge K, Fath K, Kelly T, Nuckolls G, Turner C. Focal adhesions: transmembrane junctions between the extracellular matrix and the cytoskeleton. Annu Rev Cell Biol 1988;4:487-525.

26. Patel J, Channon KM, McNeill E. The downstream regulation of chemokine receptor signalling: implications for atherosclerosis. Mediators Inflamm 2013;2013:459520.

27. Matheny RW Jr, Adamo ML. Current perspectives on Akt Akt-ivation and Akt-ions. Exp Biol Med (Maywood) 2009;234:1264-70.

28. Laine J, Künstle G, Obata T, Sha M, Noguchi M. The protooncogene TCL1 is an Akt kinase coactivator. Mol Cell 2000;6:395-407.

29. Basso AD, Solit DB, Chiosis G, Giri B, Tsichlis P, Rosen N. Akt forms an intracellular complex with heat shock protein 90 (Hsp90) and Cdc37 and is destabilized by inhibitors of Hsp90 function. J Biol Chem 2002;277:39858-66. 


\section{나노방출제어시스템을 이용하여 trichloroacetic acid와 epidermal growth factor의 순차적 방출을 적용한 인간치은섬유아세포의 세포생존 관련 유전자 연구분석}

조준연 전공의, 이성복 교수, 이석원* 교수

강동경희대학교치과병원 치과보철과 경희대학교 치과대학 치과보철학교실

목적: 본 연구에서는 구강연조직재생에서 인간치은섬유아세포에 hydrophobically modified glycol chitosan (HGC) 기 반 나노방출제어시스템을 적용 시 PI3K-AKT 신호전달의 세포생존 연관 유전자를 통해 trichloroacetic acid (TCA)와 epidermal growth factor (EGF)의 영향을 확인하고자 하였다.

연구 재료 및 방법: TCA와 EGF를 방출하는 나노방출제어시스템을 제작하였다. 실험군은 3가지 군으로 나누었다; 대조 군(CON), TCA-담지형 나노방출제어시스템 투여군(EXP1), TCA-와 EGF- 담지형 나노방출제어시스템 투여군(EXP2). 인간치은섬유아세포 배양 후 PI3K-AKT 신호전달에 연관된 총 29개 유전자를 실시간 중합효소연쇄반응으로 분석했다. 일요인 분산분석 및 다중회귀분석이 사용되었다.

결과: 세포생존 관련 유전자들은 EXP1과 EXP2에서 상향조절되었다. 다중회귀분석에서는 ITGB1이 AKT1의 발현에 가장 영향력 있는 요소로 결정되었다.

결론: $\mathrm{HGC}$ 기반 나노방출제어시스템을 통한 TCA와 EGF의 적용은 세포생존에 관한 신호전달을 상향 조절시킬 수 있다.

(구강회복응용과학지 2020;36(3): 145-57)

주요어: 인간치은섬유아세포; trichloroacetic acid; epidermal growth factor; PI3K-AKT 신호전달; 세포생존

*교신저자: 이석원

(05278)서울시 강동구 동남로 892 강동경희대학교치과병원 치과보철과

Tel: 02-440-7519 | Fax: 02-440-7549 | E-mail: ysprosth@hanmail. net

접수일: 2020년 4월 21일 | 수정일: 2020년 5월 29일 | 채택일: 2020년 6월 10일 